\title{
Engineering an Orderly Greek Debt Restructuring
}

\author{
Mitu Gulati \\ Duke University \\ Jeromin Zettelmeyer \\ European Bank for Reconstruction and Development and CEPR
}

January 29, 2012

\begin{abstract}
$\underline{\text { Abstract }}$
For some months now, discussions over how Greece will restructure its debt have been constrained by the requirement that the deal be "voluntary" - implying that Greece would continue debt service to any creditors that choose retain their old bonds rather than tender them in an exchange offer. In light of Greece's deep solvency problems and lack of agreement with its creditors so far, the notion of a voluntary debt exchange is increasingly looking like a mirage. In this essay, we describe and compare three alternative approaches that would achieve an orderly restructuring but avoid an outright default: (1) "retrofitting" and using a collective action clause (CAC) that would allow the vast majority of outstanding Greek government bonds to be restructured with the consent of a supermajority of creditors; (2) combining the use of a CAC with an exit exchange, in which consenting bondholders would receive a new English-law bond with standard creditor protections and lower face value; (3) an exit exchange in which a CAC would only be used if participation falls below a specified threshold. All three exchanges are involuntary in the sense that creditors that dissent or hold out are not repaid in full.
\end{abstract}




\title{
Engineering an Orderly Greek Debt Restructuring
}

\author{
Mitu Gulati \\ Duke University \\ Jeromin Zettelmeyer \\ European Bank for Reconstruction and Development and CEPR ${ }^{1}$
}

January 29, 2012

Greece's attempt to restructure its private sector creditors appears stuck. It has been held back by two problems. First, agreement with a committee of large institutional creditors, led by banks, has been elusive thus far. Second, conditional on such an agreement, some creditors may feel a strong temptation to free ride - that is, to hold out for full repayment. The two problems are distinct but related. Concerns about free riders may be one of the reasons why the creditor committee has been reluctant to agree to a large net present value "haircut" on its claims. Conversely, lack of such an agreement makes it much more difficult to take legal steps - for example, via socalled collective action clauses (CACs) - that would preclude free riding.

The result is a difficult situation for both Greece and its creditors. A debt restructuring within the broad parameters agreed at the October $26^{\text {th }}$ EU summit, which assumed both a large haircut and high creditor participation, is a pre-condition for continued official support. Without such support, it is hard to see how Greece can avoid a default on EUR 14.5 bn in bond repayments falling due on March 20, 2012.

This essay examines three alternative ways in which Greece and its creditors can get out of this trap. It argues that at this stage, any of these avenues requires abandoning the principle of “voluntariness" which Greece's restructuring efforts have so far respected - namely, the promise (explicit or implicit) to continue paying creditors regardless of whether they take part in the restructuring or "hold out". However, giving up the voluntariness principle does not mean that Greece's debt restructuring needs to be chaotic or unlawful. Indeed, although all three avenues discussed below would probably lead the rating agencies to declare Greece in selective default, they are unlikely to entail a default event as defined in Greece's current bond contracts. Further, one of the three avenues discussed below (Option 3) would probably not trigger Creditor Default Swap (CDS) contracts - a contributing cause of the fixation with "voluntary" restructurings, until now.

\section{The Limits of the Voluntary Approach}

Greece and its official creditors have so far insisted on the principle that any debt restructuring should be voluntary - an aim that is sometimes derided as either hypocritical or delusional by economists and the media. However, an examination of

\footnotetext{
${ }^{1}$ The views expressed in this paper are those of the authors and should not be taken to represent the views of EBRD or any other institutions that the authors are affiliated with. We thank Ross Buckley, Jonathan Charles, Christoph Denk, Anna Gelpern, Steve Rattner and Shahin Vallee for comments, without implying that they agree with our ideas.
} 
the theory and experience with voluntary debt exchanges suggests that these are not as hopeless as is often assumed. ${ }^{2}$ In a recent paper (Gulati and Zettelmeyer, 2012) we show that voluntary exchange offers can in some circumstances be consistent with large reductions in the net present value of debt. This is the case when creditors are worried that even conditional on a successful debt exchange, the country is not out of the woods, and the new bonds are expected to outperform the old bonds in the event of a future default or restructuring. This could be the case because the new bonds pay back some cash upfront (or alternatively, have a collateralised principal), or because creditors are offered foreign law bonds that afford them better protections in the event of a future restructuring. The latter is easy to do in the case of Greece, since the bulk of outstanding Greek government bonds were issued under Greek law, with minimal contractual protections. Since it is easier to involuntarily restructure these bonds than standard English-law bonds (namely, by changing domestic law), creditors who fear an involuntary restructuring should have a strong incentive to switch out of these bonds, even if at the price of a haircut. ${ }^{3}$ This argument will apply to both small and large creditors, and hence limit the temptation to free ride.

At the same time, it is easy to see the limitations of the argument. Swapping bonds against a combination of cash-on-hand and new bonds promising much lower repayments but better creditor protection will only be attractive if the alternative is to be stuck with the old bond for some time - a time period during which an involuntary restructuring might well happen. For bondholders that are expecting repayment in the near term, this is unlikely to hold: for them, the alternative is full repayment with near certainty. Hence, a voluntary exchange offer involving a 50 percent face value reduction will never persuade the holders of the EUR 14.5 bn of Greek government bonds whose final payments are due in less than two months to trade their bonds, no matter how cleverly designed. The same argument is likely to also apply, with a little less force, to other Greek government bonds coming due over the next year.

As a result, we estimate that the cost of the purely voluntary approach in restructuring the Greek debt, even under the most favourable assumptions, will be to limit the exchange to about 80 percent of eligible bonds in the hands of the private sector. In Greece's dire situation, this may just not be good enough. The prospect is also unattractive for the members of the creditor committee negotiating with Greece. No bank negotiator will relish the prospect of going before his Board of Directors to explain why he recovered 30 cents on the Euro while some hedge fund across the street recovered 100 cents. Hence, full participation should ultimately be in the interests of both Greece and creditors collectively. In this light, it makes sense that Greek officials have in recent days insisted that their objective is full, or almost full, creditor participation in the exchange.

But the inescapable implication of this objective is that the exchange cannot be fully voluntary, in the sense that holdouts must not be promised full repayment. Rather, they must expect to be (involuntarily) "bailed in" if they do not accept the exchange offer.

\footnotetext{
${ }^{2}$ For a critique of voluntary exchanges, see Aizenman et al (2005). For a historical overview and some examples, see Zettelmeyer (2012), which draws on ongoing work by Trebesch and Zettelmeyer (2012).

${ }^{3}$ The argument that voluntary or market-based sovereign debt restructurings can help reduce the debt burden if the new debt is senior (whether de jure or de facto) to the old debt is not new. It goes back at least to the 1980s. See, for example, Claessens et al (1990).
} 
There is a tool to achieve this lawfully: collective action clauses (CACs) that make a change in payment terms agreed between Greece and a qualified majority of bondholders binding for all creditors. To prevent potential holdouts from buying blocking minority positions in individual bond issues, these clauses would need to apply in the aggregate across all bonds, rather than bond-by-bond. Such clauses do not currently exist in Greek law bonds. However, they could be "retrofitted" through a change in domestic Greek law (Buchheit and Gulati, 2010).

With such clauses in place, and assuming Greece and its backers are reconciled to taking the involuntary restructuring path, there are in principle three strategies to conduct an orderly exchange that prevents free riding. The difference between the three is that the first would solely rely on CACs, the second on a combination of CACs and an exchange offer, and the third on an exchange offer in which CAC's are in the background, but would not be invoked.

\section{Option 1: Just a CAC}

The most widely used CAC allows for the "payment” terms (principal, interest, dates and currency of payment) to be modified with a vote of 75 percent or more of the bonds in principal amount. Assuming Greece can obtain agreement from the necessary 75 percent to reduce its payment obligations, it can force the remaining creditors to agree. Eighteen months ago, when the vast majority of Greek bonds were in the hands of European financial institutions, obtaining this vote may have been a relatively easy matter. These financial institutions would have both had sufficiently large holdings of Greek debt and have been sufficiently involved in business relationships with Greece and its official creditors to resist the temptation to free ride. Today, however, many of those bonds have migrated into the hands of hedge funds whose strategy is to hold out from any attempt at restructuring in the hope of getting paid in full or extract a favourable settlement. Another complicating factor is that a large volume of bonds - perhaps up to 20 percent of outstanding Greek government bonds - are in the hands of the European Central Bank (ECB). The members of Greece's creditor committee are hence likely to represent significantly less than 75 percent of the face value of the debt outstanding. Assuming that the ECB would not be voting its bonds (it has so far resisted any haircut on its holdings), this makes it virtually impossible for Greece to get past the magic 75 percent threshold it needs so as to implement the CAC.

There are potential solutions to these problems, but none of them is easy. A solution to the ECB problem would be for Greece to buy back its government bonds from the ECB at the price at which the ECB bought them on the market. Alternatively, the ECB could participate in the restructuring on condition that Greece compensates it for the difference between the value of the new bonds and the value at which it bought the old bonds. Either of these solutions would avoid a fiscal transfer from the ECB to the Greek sovereign in potential contravention of its mandate. ${ }^{4}$ Assuming that the ECB would agree to this, there remains the problem of how Greece would obtain the funds to pay for a buy-back from or compensation to the ECB. In all likelihood, this

\footnotetext{
${ }^{4}$ It would also take account of the fact that the ECB secondary market purchases were part of an official crisis intervention. That arguably gives it an informal claim to seniority over the private sector (as is typically claimed by the IMF).
} 
would require additional financing from the official creditors (for example, through the EFSF).

But even assuming the ECB holdings could be brought into the voting pool, the necessary super majority of seventy-five percent might be hard to reach. One option here is to reduce the vote required to alter payment terms (for example, to a simple majority). At first cut, this does not appear difficult. After all, Greece is retrofitting the CACs by legislative fiat. If it can retrofit a 75 percent vote requirement to change payment terms, it can just as easily use 50 percent. The problem, however, is that the further below 75 percent the vote threshold gets moved, the more the risk of litigation increases. Seventy-five percent is a magic number because it is, roughly speaking, the dominant market standard. ${ }^{5}$ As best we are aware, it is also likely to be the standard for the new model Eurozone CACs that every Eurozone sovereign debt instrument is supposed to include starting later this year. A court, in deciding whether the Greek state acted unlawfully implementing the retrofit CACs is likely to take into consideration the fact that Greece did nothing more than utilize the market standard provision.

Another option would be to specify that the 75 percent applies in the context of a physical meeting of the bondholders and where the denominator is the number of bondholders who show up to the meeting or submit proxies, subject to a reasonable quorum requirement, such as 50 percent. This particular formulation of a CAC, where the vote takes place as a function of a meeting, is a less widely used formulation than the one discussed above. However, it is still a familiar formulation, particularly in sovereign bonds issued under English law. There are downsides though. First, utilizing the CAC plus meeting mechanism will mean that Greece will first have to give creditors some reasonable amount of notice (our impression is that roughly three weeks is standard) so as to pass muster with a court. Given the urgency with which the deal needs to get done, Greece may not have the luxury of being able to provide a three-week notice period. Second, there is a reason why the practice of requiring meetings among bondholders has been waning. Allowing creditors to have a meeting might enable them to coordinate over how to better resist the Greek offer.

\section{Option 2. A CAC Plus an Exit Exchange}

Assuming Greece has difficulty getting 75 percent of the creditors to agree to its exchange offer, the next step is to ask how it might further incentivize creditors to take the deal. One way to do that is to combine the CAC with what is called an Exit Exchange offer. As with Option 1 (Just a CAC), Greece would ask its creditors to vote in favour of reducing its payment obligations. The difference would be that here, in exchange for their vote, Greece would allow each consenting bondholder to exit their old Greek law bonds and enter into new English law bonds, involving some cash-on-hand but 50 percent lower face value, that would be bolstered by a variety of standard contractual protections (negative pledge clauses, pari passu clauses, cross default clauses, etc.) that standard English law bonds contain but the local Greek law bonds do not.

\footnotetext{
${ }^{5}$ Seventy-five percent is the typical vote requirement to change payment terms in individual sovereign bond issues today. The type of CAC being contemplated for Greece, however, is an aggregation provision that is not typically found in sovereign bonds. And to the extent it has been used by a handful of sovereigns such as Uruguay, the required vote at the aggregated level is 85 percent.
} 
A debt exchange offer of this type might be persuasive even to small creditors who are potential free riders, because they would not want to be left with bonds that both have had their payment obligations modified (via a CAC) and have been de facto subordinated. In the next restructuring, the local law bonds would remain highly vulnerable, whereas the English-law bonds will be relatively protected. If a new restructuring is viewed as sufficiently likely, this would provide a powerful incentive to take the offer, and hence lead to higher participation. Further, the litigation risk from taking this approach is low. In contrast to past restructurings, when the Exit Exchange technique was used to take away rights of existing bondholders by changing the non-payment terms of their bonds, ${ }^{6}$ the technique offers an upgrade of creditor rights to creditors that accept the exchange offer (Gulati and Zettelmeyer, 2012).

The benefit of this technique of combining a CAC and an Exit Exchange is that it has the potential to obtain a very high level of creditor consent. Prior uses of this technique in the sovereign context have garnered upwards of 90 percent creditor participation. That means that Greece might be able to get to a 75 percent vote even without buying back the ECB bonds or having the ECB vote in favour of exchanging its bonds, though the latter would clearly be the safer approach.

\section{Option 3. An Exit Exchange in the Shadow of a CAC}

An important motivation for trying to do the Greek debt exchange on a voluntary basis was a concern about triggering CDS contracts written on Greek debt. Both of the options described above would trigger the standard CDS. If a CAC is used to bind a dissenting minority of creditors, that typically constitutes a "restructuring" credit event for purposes of these CDS contracts. However, there may be a way of combining a CAC and an exchange offer that would not actually lead to the use of CACs "in equilibrium” (to use the economists' patois). In other words, a CAC would be retrofitted and the use of the CAC would be explicitly or implicitly threatened but would not be invoked. This approach would work as long as a supermajority required to invoke the CAC is inclined to take the exchange offer, so that the threat is credible.

To see how this would need to be designed, suppose that Greece first undertakes an exit exchange and then activates a CAC if participation in the exchange has fallen short of the objective. This strategy will not work. By the time that Greece would want to invoke the CAC (say because only 75 percent rather than the desired 99 percent or more exchanged their bonds), all of the creditors who would have voted for the CAC would have already exited. The only creditors left to apply the CAC will be those who oppose it; and these creditors will presumably vote against its use.

However, there is a way to modify the sequence of events that gets around that problem. Many past restructurings have involved exchange offers that were conditional on minimum participation thresholds. In this case, the mechanics of the offer envisages two stages. First, bondholders are invited to submit irrevocable commitments to tender their bonds, conditional on a minimum overall participation in

\footnotetext{
${ }^{6}$ The sovereigns that have used this technique are Ecuador (2000), Uruguay (2003) and the Dominican Republic (2005). On the use of this technique, see Sturzenegger and Zettelmeyer (2007); Buchheit and Gulati (2000).
} 
the exchange. In a second stage, an exchange agent first verifies whether the overall participation in the exchange exceeded the pre-specified threshold. Only if this is the case do bondholders that agreed to tender receive their new bonds, and the title to the old bonds passes to the debtor.

Now suppose that in the first stage, bondholders are invited not just to submit commitments to tender their old bonds conditional on a minimum participation level. They are also asked to authorise the exchange agent to vote on their behalf for a prespecified change in the payment terms of the old bonds if and only if participation does not exceed a second, higher threshold. For example, the offer could specify that:

- If participation falls below 75 percent - which we assume to be the threshold at which CACs can be invoked - the exchange offer is withdrawn;

- If participation exceeds 99 percent, the exchange is carried out without the activation of the CACs - and investors are given to understand that any holdouts may not be repaid;

- If participation is between 75 and 99 percent, then first a ballot is convened at which existing bondholders - which include the individuals committed to tendering - vote to change the payment terms of the old bonds to align them with those of the newly offered bonds. Only after that does the exchange become effective, new bonds are issued, and the old bonds change title.

Provided that it is credible that the 75 percent threshold will be reached, the effect of an offer that is structured in this manner would be to eliminate all holdouts and reach 100 percent participation (except for investors somehow did not notice that an exchange was being offered). The reason is that in these circumstances, investors will always do at least as well by tendering than by holding out. If participation is near universal (99 percent or more) and the creditor nonetheless holds out, she must fear not getting repaid. If, however, participation falls between 75 and 99 percent, then the CAC will be used, and holdouts will end up with an old, Greek law instrument whose (modified) payment terms are not better than those of the new English law bonds.

As a result, participation would be near universal, ${ }^{7}$ CACs would not be invoked, and Greece might avoid being labelled "in default". Further, there is a good argument - at least based on the ISDA pronouncements so far - that the CDS contracts on Greek debt would not be triggered.

\section{A Complication with Silver Linings: The Foreign-Law Bonds}

In recent discussions regarding a possible Greek restructuring, the complication posed by Greece's stock of English- and Swiss-law bonds has largely been ignored. We do not have concrete figures on the exact amounts outstanding, but our guess is that there is about 15-20 bn Euros of such debt. That is not an amount that Greece can afford to

\footnotetext{
${ }^{7}$ We say "near universal” because apart from creditors that make a mistake or missed the deadline, it is possible that some creditors would hold out for the express purpose of litigating. However, one would expect this group to be very small, if it exists at all, since the prospect of suing in a Greek court must be distinctly unattractive to a holdouts, including because any proceeding would be expected to continue for years, and because a Greek court is likely to be less sympathetic to a litiguous holdout than a foreign court. Consistent with this, market reports indicate that distressed debt funds that specialize in litigation have bought English-law rather than Greek-law bonds (White and Wilkes, 2012).
} 
ignore, given its current financial state. Furthermore, if press reports that hedge funds hold a high percentage of these bonds are correct, paying them in full while imposing costs on Eurozone taxpayers will be a distasteful pill for Eurozone politicians to swallow. Hence, these bonds will need to be restructured.

To what extent would the three restructuring options described above carry over to these foreign-law bonds? They do, but all of them would be less effective in the sense that it could be harder (or, for a given quality of the offer, less likely) to obtain the majorities to make them work.

- Option 1: Just CACs. Greek foreign-law bonds have CACs but do not have aggregation clauses. Hence, they need to be voted on bond-by-bond. This makes it even more difficult to obtain the requisite (75 percent) supermajority, particularly since it is conceivable that in some cases distressed debt funds have acquired sufficiently large shares (that is, greater than 25 percent) of individual bond series that would effectively give them a veto over the restructuring using CACs.

- Option 2: CACs plus an Exit Exchange. In the form described in the previous section, this technique would not add anything to the "Just CACs" option for foreign law bonds, because one cannot incentivize the holders of these bonds to vote in favour of payment reductions by promising them enhanced contractual protections of the type typically found in English-law sovereign bonds (they already have them!). ${ }^{8}$ This said, it might be possible to use the conventional Exit Exchange technique as a stick rather than a carrot, that is, by asking exiting bondholders to consent to a change in non-payment terms that would strip creditors' protections from the remaining old bonds. ${ }^{9}$

- Option 3: Exit exchange in the shadow of a CAC. Again, this approach is possible but more difficult to pull off, because it relies on a credible threat that CACs will actually be used. Without aggregation clauses and with the possibility that some creditors may have bought blocking shares, this is more difficult, and the use of the Exit Exchange technique may not help much.

To conclude, the bargaining power of creditors is likely to be higher for the Englishlaw bonds than for the Greek-law bonds, particularly when individual creditors own sufficient bonds to block the use of CACs. In these cases, the Greek government may not have a choice but to negotiate and settle with these creditors. In other cases, any of the three Options remains feasible, with Options 2 and 3 offering the relatively largest chance of success if combined with an Exit Exchange offer. But even with this added incentive, persuading the holders of English-law bonds to accept an exchange offer is likely to require a better offer than in the case of the Greek-law bonds (Choi, Gulati and Posner, 2011).

There are a couple of silver linings to the foregoing though. First, the higher payments to these holders of foreign-law bonds will confirm to the holders of locallaw bonds the reality that they will be de facto subordinated if they do not tender. This

\footnotetext{
${ }^{8}$ The voting threshold for changes in non-payment terms in the outstanding Greek English-law bonds that we have seen are almost as high (67 percent) as for the changes to payment terms. Hence, compared to "Just CACs", this will help only if the supermajority in favor of the exchange is higher than 67 but lower than 75 percent.

${ }^{9}$ These are also known as “Exit Consents”, and were used in Ecuador's 2003 exchange. See note 6.
} 
may help convince the holders of the Greek-law bonds accept an exchange offer in which they are offered an "upgrade" to English-law bonds. Second, Greece is going to want to tap the international bond markets again. It is going to be a long time, however, before foreign investors are going to be willing to lend to Greece in locallaw bonds again. However, if Greece treats its English-law bonds well and in a manner consistent with their superior contractual protections, it may be able to issue new English-law bonds relatively soon.

\section{The Steps Ahead}

A recurring theme in the discussion so far is that the effectiveness in bringing potential holdouts to the table will depend on the credibility of the prospect that CACs would actually be invoked. "Retrofitting" such a clause is not by itself enough to solve the problem. Hence, Greece needs to continue bargaining in good faith with the institutional creditors to secure the supermajority to invoke it. Even with the reassurance that holdouts will not go scot free, there is a limit to which institutional creditors can be squeezed. In particular, the haircut Greece can extract from creditors will be limited by an outside option available to all creditors: to sell their bonds to "distressed debt funds" that would acquire them purely for the purposes of litigation and eventual settlement. The business model of these funds requires them to buy debt at very low prices - our guess is someplace below 20 cents for each Euro of face value - to make risky litigation and settlement negotiations worthwhile. That said, in the case of Greece, which is bound not only by domestic law and courts but also by EU law and EU institutions, the prospects for successful litigation might be higher than is typical, and hence the minimum value that creditors must be offered in order to accept might also be higher.

Among the three options presented above, Options 2 or 3 offer the best prospects of achieving a high haircut with universal or near-universal creditor participation. Which among these two options is preferable depends on whether invoking CDS (which would happen for sure under Option 2) is viewed as a problem or not. ${ }^{10}$ Either option requires a 75 creditor percent participation, which ideally would be secured through a negotiated agreement. If, however, such an agreement were to remain elusive, Greece can and attempt to implement either of these options in the form of a unilateral exchange offer - the standard approach used in emerging market crises in the last 15 year. Even without the backing of a CAC, this has often been successful (Bi et al, 2011). Specifically, it should make private sector creditors the best offer it can afford with the backing of its official creditors. It should offer some cash upfront - 15 cents on the Euro is a good number - as well as an upgrade in the bond contracts that make them harder to restructure in the event of a new crisis. It should set a minimum participation threshold of at least 75 percent below which the offer would be retracted. And it should make it clear that it does not commit to repaying holdouts on the old terms.

\footnotetext{
${ }^{10}$ This difference in Option 2 and Option 3 in terms of whether the CDS contracts will be triggered is only relevant if one assumes that Greece will not have to use CACs to restructure its foreign-law bonds (that is, if Option 3 will also be successful in the case of the foreign-law bonds). If not, the restructuring of the foreign-law bonds would trigger the typical CDS contracts regardless of whether Option 2 or Option 3 is used with the local-law bonds. This is because the typical CDS contract is written on a package of loans and bonds from the entity (here, Greece) as opposed to on a single bond.
} 
If this happens, the holders of its English-law and Swiss-law bonds will likely be able to accelerate their obligations and sue in foreign courts. They may even be able to attach some assets and obtain partial payment. The holders of local-law Greek bonds though will have to bring their claims under Greek law and in Greek courts. That is not going to be an attractive proposition to any creditor. With this approach, it is likely to get high participation -- perhaps not 99 percent, but well in excess of the minimum participation threshold. There would be litigation, but it would be limited. This is the best that Greece can and should do under worst case assumptions.

Among Greece’s many problems, conducting a successful orderly debt exchange involving a large haircut is perhaps the most tractable. It may not by itself restore Greece to solvency, but it is likely to be a critical component of any comprehensive solution. With good design, good faith, and speed, it could succeed.

\section{References}

Aizenman, Joshua, Kenneth M. Kletzer, and Brian Pinto. 2005. Sargent-Wallace Meets Krugman-Flood-Garber, or: Why Sovereign Debt Swaps Do Not Avert Macroeconomic Crises. Economic Journal, Vol. 115, No. 503: 343-367.

Bi, Ran, Marcos Chamon, and Jeromin Zettelmeyer. 2011. The Problem That Wasn’t: Coordination Failures in Sovereign Debt Restructurings. IMF Working Paper WP/11/265. Washington: International Monetary Fund.

Buchheit, Lee C., and Mitu Gulati. 2010. How to Restructure Greek Debt. Duke Law Working Paper 47. (http://papers.ssrn.com/sol3/papers.cfm?abstract_id=1603304).

Buchheit, Lee C., and Mitu Gulati. 2000. Exit Consents in Sovereign Bond Exchanges. UCLA Law Review. Volume 48, 59-84.

Choi, Stephen J., Mitu Gulati and Eric A. Posner. 2011. Pricing Contract Terms in Sovereign Debt Contracts: A Greek Case Study. Capital Markets Law Journal. Volume 6, 163-187.

Claessens, Stijn, Ishac Diwan, Kenneth A. Froot, and Paul R. Krugman. 1990. Market-Based Debt Reduction for Developing Countries: Principles and Prospects. Washington: The World Bank.

Gulati, Mitu, and Jeromin Zettelmeyer. 2012. Making a Voluntary Greek Debt Exchange Work. CEPR Discussion Paper 8754, January (forthcoming Capital Markets Law Journal) (http://papers.ssrn.com/sol3/papers.cfm?abstract_id=1979474).

Sturzenegger, Federico, and Jeromin Zettelmeyer. 2007. Debt Defaults and Lessons from a Decade of Crises. Cambridge, MA: MIT Press.

Trebesch, Christoph, and Jeromin Zettelmeyer. 2012. Do Voluntary Exchanges Ever Work? (work in progress). 
White, Sarah and Tommy Wilkes. 2012. Hedge Funds Prepare Legal Battle With Greece. Cyprus Mail, January 24.

Zettelmeyer, Jeromin, 2012. How to do a Sovereign Debt Restructuring in the Eurozone: Lessons from Emerging Market Debt Crises. CEPR Discussion Paper, February. 